ISSN: 2302-8556

E-Jurnal Akuntansi Universitas Udayana

Vol.27.2.Mei (2019): 1546-1569

DOI: https://doi.org/10.24843/EJA.2019.v27.i02.p27

\title{
Pengaruh Kompensasi Manajemen, Inventory Intensity Ratio, dan Profitabilitas Pada Tax Avoidance
}

\author{
Komang Dessica Indriyanti ${ }^{1}$ \\ Putu Ery Setiawan ${ }^{2}$ \\ ${ }^{1,2}$ Fakultas Ekonomi dan Bisnis Universitas Udayana (Unud), Bali, Indonesia \\ e-mail: indriyanti.sika@yahoo.co.id
}

\begin{abstract}
ABSTRAK
Tujuan penelitian ini yaitu untuk meneliti pengaruh kompensasi manajemen, inventory intensity ratio, dan profitabilitas pada tax avoidance. Penelitian ini dilakukan di perusahaan manufaktur yang terdaftar di Bursa Efek Indonesia (BEI) tahun 2013-2017. Jumlah pengamatan yang diperoleh adalah sebanyak 205 pengamatan dengan menggunakan metode nonprobability sampling yaitu purposive sampling. Teknik analisis data yang digunakan yaitu analisis regresi linier berganda. Hasil analisis regresi linier berganda menujukkan bahwa kompensasi manajemen berpengaruh negatif pada tax avoidance, Profitabilitas berpengaruh positif pada tax avoidance, sedangkan Inventory intensity ratio tidak berpengaruh pada tax avoidance.
\end{abstract}

Kata Kunci: Kompensasi manajemen, inventory intesity ratio, profitabilitas, dan tax avoidance

\section{ABSTRACT}

The purpose of this study is to examine the effect of management compensation, inventory intensity ratio, and profitability on tax avoidance. This research was conducted at a manufacturing company listed on the Indonesia Stock Exchange (IDX) in 2013-2017. The number of observations obtained was 205 observations using the nonprobability sampling method, namely purposive sampling. The data analysis technique used is multiple linear regression analysis. The results of multiple linear regression analysis show that management compensation has a negative effect on tax avoidance, profitability has a positive effect on tax avoidance, while the inventory intensity ratio does not affect tax avoidance.

Keywords : Management compensation, inventory intensity ratio, profitability, tax avoidance

\section{PENDAHULUAN}

Tax avoidance adalah usaha dalam menurunkan jumlah pajak terutang dengan cara yang legal, usaha ini menimbulkan risiko bagi perusahaan antara lain buruknya reputasi perusahaan dimata publik (Xynas, 2011). Tax avoidance menggambarkan strategi perencanaan pajak seperti manajemen pajak (tax management), perencanaan pajak (tax planning), pajak agresif (tax aggressive), tax evasion, dan tax sheltering (Hanlon \& Heitzman, 2010). Fenomena tax avoidance tercermin dari SKPKB (Surat Ketetapan Pajak Kurang Bayar) yang 
diterima perusahaan. SKPKB adalah surat ketetapan pajak yang terdiri dari besarnya pembayaran pokok pajak, jumlah pokok pajak, jumlah kredit pajak, jumlah sanksi administrasi, dan jumlah yang masih harus dibayar. Terdapat 49 perusahaan manufaktur dalam kurun waktu lima tahun yang menerima SKPKB. Jumlah penerimaan SKPKB yang berfluktuasi oleh perusahaan manufaktur selama periode 2013-2017 mengindikasikan bahwa perusahaan berusaha melakukan tindakan penghindaran pajak (tax avoidance) agar lebih sedikit dalam pembayaran pajak. Data perusahaan penerima SKPKB disajikan pada tabel 1:

Tabel 1.

Perusahaan Manufaktur Penerima SKPKB Tahun 2013-2017

\begin{tabular}{lllr}
\hline & & \multicolumn{2}{c}{ Keterangan } \\
\cline { 3 - 4 } No & Tahun & Jumlah Perusahaan & Nilai SKPKB $(\mathrm{Rp})$ \\
\hline 1 & 2013 & 5 & 75.323 .071 .070 \\
2 & 2014 & 10 & 69.187 .625 .543 \\
3 & 2015 & 10 & 136.639 .677 .300 \\
4 & 2016 & 15 & 318.842 .492 .365 \\
5 & 2017 & 12 & 82.338 .507 .889 \\
\hline
\end{tabular}

Sumber: Annual Report Perusahaan Manufaktur, 2018

Kompensasi manajemen yang diberikan dengan tepat diharapkan dapat mendorong manajemen untuk mengambil strategi paling tepat dalam pelaksanaan tax avoidance (Chalmers, Koh, \& Stapledon, 2006). Menurut Irawan \& Farahmita (2012) dengan kebijakan kompensasi yang tepat, pemilik perusahaan mengharapkan dapat meningkatkan kinerja manajemen pada perusahaan yang akan berpengaruh pada nilai perusahaan secara menyeluruh (Mccolgan, 2001). Penelitian yang dilakukan oleh Putri (2017) dan Gaertner et al. (2010) menemukan adanya hubungan yang positif dan signifikan antara pemberian kompensasi manajemen terhadap tax avoidance. Hasil ini berlawanan dengan 
penelitian Minnick dan Noga (2010) dan Armstrong et al. (2015) yang menemukan hubungan negatif antara peningkatan kompensasi dengan pembayaran pajak perusahaan.

Faktor lain yang dapat menimbulkan tax avoidance yaitu inventory intensity ratio. Besarnya intensitas persedian dapat menimbulkan biaya tambahan yang dapat mengurangi laba perusahaan dan mengurangi jumlah pajak yang dibayarkan perusahaan. Penelitian tentang intensitas persediaan yang dilakukan oleh Richardson dan Lanis (2007) dan Noor et al. (2010) menemukan bahwa intensitas persediaan mengakibatkan meningkatnya pajak yang akan dibayarkan oleh perusahaan. Hasil penelitian Surbakti (2012) menunjukkan bahwa inventory intensity ratio berpengaruh negatif terhadap penghindaran pajak (tax avoidance). Sedangkan hasil penelitian yang dilakukan Lestari (2015), Siregar dan Widyawati (2016) menemukan bahwa inventory intensity ratio tidak berpengaruh terhadap penghindaran pajak (tax avoidance). Perbedaan teori dan penelitian yang telah dilakukan, mendorong perlunya penelitian lebih lanjut mengenai pengaruh intensitas persediaan terhadap pajak yang dibayar oleh perusahaan.

Profitabilitas merupakan kemampuan perusahaan untuk menghasilkan laba, pengukuran profitabilitas dapat diukur dengan menggunakan proksi Return On Asset (ROA) (Nugrahitha \& Suprasto, 2018). Perusahaan yang memiliki profitabilitas tinggi akan merencanakan perilaku yang taat dan patuh membayar beban pajaknya karena perusahaan dengan profit yang tinggi dianggap mampu membayar pajaknya. Penelitian yang dilakukan oleh Faizah dkk. (2017) dan Fajar dkk. (2018) yang menyatakan profitabilitas berpengaruh negatif terhadap 
penghindaran pajak. Hasil ini berlawanan dengan penelitian yang dilakukan oleh Darmawan \& Sukartha (2014) yang menyatakan bahwa ROA berpengaruh positif pada tax avoidance.

Penelitian ini dilakukan pada perusahaan manufaktur yang terdaftar di Bursa Efek Indonesia (BEI) dari tahun 2013-2017. Alasan pemilihan perusahaan manufaktur sebagai objek penelitian yaitu: perusahaan manufaktur memiliki jumlah perusahaan manufaktur memiliki proporsi yang besar di Bursa Efek Indonesia sehingga memiliki variasi data yang besar, perusahaan manufaktur adalah perusahaan penyumbang penerimaan pajak negara terbesar. Hal ini terlihat sepanjang 2017 penerimaan pajak dari sektor manufaktur tercatat tumbuh 17,1 persen, industri manufaktur juga memberi kontribusi tertinggi sebagai penyetor pajak. Selain itu, perusahaan manufaktur menjadi wajib pajak yang difokuskan dalam daftar pemeriksaan Direktorat Jendral Pajak. Periode 2013-2017 dipilih karena merupakan data terbaru yang dpat diperoleh dan diharapkan dengan periode waktu lima tahun dapat memeroleh hasil yang baik dalam menjelaskan pengaruh kompensasi manajemen, inventory intensity ratio, dan profitabilitas pada tax avoidance.

Pemberian kompensasi manajemen yang bertujuan untuk meningkatkan kualitas kinerja perusahaan, sehingga dapat meningkatkan keuntungan perusahaan. Peningkatan keuntungan perusahaan akan berdampak terhadap ETR perusahaan yang digunakan sebagai rasio pengukuran tax avoidance. Profitabilitas perusahaan yang meningkat akan menyebabkan ETR perusahaan meningkat. ETR yang meningkat menunjukkan tax avoidance yang menurun. Jadi ketika 
kompensasi manajemen perusahaan meningkat, maka tax avoidance akan menurun.

Theory of Planned Behavior menjelaskan bahwa perilaku individu terhadap perilaku tertentu diakibatkan oleh niat seorang individu (Ajzen, 1991). Niat tersebut muncul dari beberapa faktor, salah satunya yaitu kontrol keperilakukan. Kompensasi diberikan sebagai kontrol terhadap kinerja manajemen yang kebanyakan dihitung berdasarkan profitabilitas, oleh karena itu manajemen cenderung lebih oportunis dalam melakukan penghindaran pajak, disisi lain pemilik menginginkan keberlanjutan dalam perusahaannya tetap terjamin dan investasi yang aman, hal inilah yang mendorong pemberian kompensasi kepada manajemen untuk meminimalkan tindakan oportunistik manajemen dalam melakukan penghindaran pajak.

Armstrong et al. (2012) dan Zulma (2016) mendapatkan adanya pengaruh negatif antara kompensasi manajemen dengan penghindaran pajak. Perusahaan yang melakukan tax avoidance, dapat mengakibatkan ketidakpastian yaitu ketidakpastian dalam risiko terhadap pelanggaran hukum bagi perusahaan (Murphy, 2004). Penghindaran pajak dapat mengakibatkan risiko bagi masa depan perusahaan sehingga pemilik akan memberikan sejumlah kompensasi terhadap manajemen untuk menekan sikap oportunis dalam melakukan penghindaran pajak. Hipotesis pertama dinyatakan sebagai berikut:

$\mathrm{H}_{1}$ : Kompensasi manajemen berpengaruh negatif pada tax avoidance.

Intensitas persediaan menunjukkan perusahaan dalam melakukan investasi terhadap persediaannya. PSAK No.14 membahas mengenai jumlah biaya 
kepemilikan persediaan yang tinggi harus dipisahkan dari biaya persediaan dan diakui sebagai beban selama periode terjadinya biaya. Beban yang timbul atas persediaan dapat mengurangi laba perusahaan. Laba perusahaan yang menurun menyebabkan ETR perusahaan menurun. Penurunan ETR mengindikasikan tax avoidance yang meningkat. Jadi ketika inventory intensity ratio perusahaan meningkat, maka tax avoidance akan meningkat.

Sesuai dengan theory of planned behavior biaya tambahan atas persediaan akan mendorong intensi dalam penurunan laba yang akan membentuk sikap (attitude) dengan melakukan tax avoidance. Intensi timbul dari keyakinan (beliefs) manajemen terhadap harapan normatif orang. Pihak prinsipal memiliki harapan untuk memeroleh pembayaran beban seminimal mungkin sehingga memeroleh keuntungan tinggi dan menjadi motivasi pihak manajemen untuk memenuhi harapan tersebut (normative beliefs). Hipotesis kedua dinyatakan sebagai berikut:

$\mathrm{H}_{2}$ : Inventory intensity ratio berpengaruh positif pada tax avoidance.

Profitabilitas adalah kemampuan perusahaan dalam menghasilkan laba atau keuntungan. Profitabilitas terdiri dari beberapa rasio, salah satunya adalah return on assets. Return on Assets (ROA). Profitabilitas perusahaan yang meningkat akan menyebabkan ETR perusahaan meningkat. ETR yang meningkat menunjukkan tax avoidance yang menurun. Jadi ketika profitabilitas perusahaan meningkat, maka tax avoidance akan menurun.

Sesuai dengan Theory of Planned of Behaviour, ketika perusahaan memiliki profitabilitas yang tinggi, maka perusahaan akan merencanakan perilaku 
yang taat dan patuh membayar beban pajaknya karena perusahaan dengan profit yang tinggi dianggap mampu membayar pajaknya sehingga menurunnya tindakan tax avoidance. Slemrord (1989) menyatakan bahwa perusahaan dengan profitabilitas tinggi pada umumnya lebih taat dalam melaporkan pajaknya secara jujur dibandingkan perusahaan dengan profitabilitas yang rendah. Perusahaan dengan profitabilitas rendah biasanya berada dalam kondisi keuangan yang buruk(financial difficulty) sehingga cenderung akan melakukan ketidakpatuhan pajak. Perusahaan dengan profitabilitas tinggi mempunyai kesempatan dalam melakukan tax planning yang dapat mengurangi jumlah beban kewajiban perpajakan (Chen, et al., 2010). Sesuai dengan penelitian Dewinta \& Setiawan (2016) yang menyatakan bahwa profitabilitas berpengaruh positif terhadap tax avoidance. Hipotesis ketiga dinyatakan sebagai berikut:

$\mathrm{H}_{3}$ : Profitabilitas berpengaruh negatif pada tax avoidance.

\section{METODE PENELITIAN}

Metode penelitian ini menggunakan metode kuantitatif. Pendekatan kuantitatif merupakan pendekatan yang digunakan untuk meneliti populasi atau sampel dengan tujuan untuk menguji hipotesis yang telah ditetapkan (Sugiyono, 2009:13). Sampel yang diambil adalah perusahaan manufaktur di Bursa Efek Indonesia yang dipilih dengan menggunakan metode purposive sampling dengan kriteria sebagai berikut: (1) Perusahaan manufaktur yang telah terdaftar di Bursa Efek Indonesia dan tidak delisting selama periode 31 Desember 2013 sampai dengan 31 Desember 2017. (2) Perusahaan manufaktur yang menerbitkan laporan keuangan di BEI tahun 2013-2017. (3) Perusahaan manufaktur yang melakukan 
pembukuan dengan menggunakan mata uang rupiah. (4) Perusahaan manufaktur yang memiliki laba bernilai positif untuk tahun 2013-2017. Perusahaan yang mengalami kerugian tidak memiliki kewajiban untuk membayar pajak, sehingga akan menghasilkan tarif pajak efektif yang terdistorsi Omer et al, (1993). (5) Perusahaan manufaktur yang mencantumkan kompensasi manajemen dalam laporan keuangan.

Penelitian dilakukan dengan melakukan analisis pada perusahaanperusahaan manufaktur yang terdaftar di Bursa Efek Indonesia (BEI) tahun 20132017 dan telah menerbitkan laporan tahunan yang dapat diakses melalui website www.idx.co.id. Objek penelitian ini yaitu tax avoidance yang dipengaruhi oleh kompensasi manajemen, inventory intensity ratio, dan profitabilitas.

Variabel dalam penelitian ini yaitu: variabel terikat dan variabel bebas. Variabel terikat yang digunakan dalam penelitian ini yaitu tax avoidance (Y). Penelitian ini menggunakan proksi Generally Accepted Accounting Principles Effective Tax Rate (GAAP ETR). GAAP ETR merupakan ukuran hasil berbasis laporan laba rugi yang secara umum mengukur efektivitas dari strategi pengurangan pajak. GAAP ETR dapat dihitung dengan rumus sebagai berikut:

$\mathrm{ETR}=\frac{\text { Beban pajak }}{\text { Laba sebelum pajak }}$

Variabel bebas dalam penelitian ini yaitu kompensasi manajemen $\left(\mathrm{X}_{1}\right)$. Kompensasi manajemen diukur dengan proksi logaritma natural dari nilai total kompensasi yang diterima direksi selama satu tahun. Data kompensasi direksi dapat dilihat dalam pengungkapan Catatan atas Laporan Keuangan Perusahaan. Inventory intensity ratio $\left(\mathrm{X}_{2}\right)$ dapat dihitung dengan membandingkan nilai 
persediaan dengan total aset perusahaan, inventory intensity ratio dihitung sebagai berikut (Darmadi \& Zulaikha, 2013)

Inventory Intensity Ratio $=\frac{\text { Total Persediaan }}{\text { Total Aset }}$

Profitabilitas $\left(\mathrm{X}_{3}\right)$ digunakan sebagai pengukur efisiensi penggunaan modal dalam suatu perusahaan dengan membandingkan antara modal yang digunakan dengan laba operasi yang dicapai. Profitabilitas perusahaan dapat diukur dengan menggunakan proksi return on asset (ROA) (Minnick dan Noga, 2010). Perhitungan ROA yaitu laba bersih yang dibandingkan dengan total aset pada akhir periode, rumus yang digunakan yaitu sebagai berikut:

ROA $=\frac{\text { Laba Bersih Setelah Pajak }}{\text { Total Aset }} \times 100 \%$

Populasi yang digunakan yaitu seluruh perusahaan manufaktur yang terdaftar di Bursa Efek Indonesia (BEI) dengan periode selama lima tahun yaitu tahun 2013-2017. Data kuantitatif pada penelitian ini yaitu laporan keuangan perusahaan manufaktur yang terdaftar di BEI tahun 2013-2017. Data kualitatif pada penelitian ini yaitu penelitian terdahulu yang dapat mendukung hasil analisis. Penelitian ini menggunakan data sekunder berupa laporan keuangan seluruh perusahaan yang telah diaudit yang terdaftar di Bursa Efek Indonesia (BEI) tahun 2013-2017. Sumber data dapat diperoleh dari situs resmi BEI di www.idx.co.id.

Penelitian ini menggunakan metode observasi non partisipan untuk pengumpulan data. Observasi non partisipan dalam penelitian ini dilakukan dengan cara: studi pustaka dan studi dokumentasi. Teknik analisis data yang 
digunakan dalam penelitian ini yaitu analisis regresi linier berganda. Penggunaan analisis regresi linier berganda (multiple linier regression analysis) untuk menguji pengaruh dua atau lebih variabel independen terhadap variabel dependen. Adapun persamaan dalam menguji hipotesis secara keseluruhan pada penelitian ini yaitu sebagai berikut:

$$
Y=\alpha+\beta_{1} X_{1}+\beta_{2} X_{2}+\beta_{3} X_{3}+e
$$

\section{Keterangan :}

$$
\begin{array}{ll}
\mathrm{Y} & =\text { Tax avoidance } \\
\alpha & =\text { Nilai Konstanta } \\
\beta_{1} & =\text { Koefisien Regresi Kompensasi Manajemen } \\
\beta_{2} & =\text { Koefisien Regresi Inventory Intensity Ratio } \\
\beta_{3} & =\text { Koefisien Regresi Profitabilitas } \\
\mathrm{X}_{1} & =\text { Kompensasi Manajemen } \\
\mathrm{X}_{2} & =\text { Inventory Intensity Ratio } \\
\mathrm{X}_{3} & =\text { Profitabilitas } \\
\mathrm{e} & =\text { Error }
\end{array}
$$

Tahap analisis yang dilakukan adalah statistik deskriptif, uji asumsi klasik, analisis regresi linier berganda, dan pengujian hipotesis.

\section{HASIL DAN PEMBAHASAN}

Perusahaan dipilih dengan teknik purposive sampling sesuai dengan kriteria yang telah ditentukan. Proses pemilihan sampel dalam penelitian ini menghasilkan data yang disajikan dalam tabel 2. 
Tabel 2.

Proses Seleksi Sampel

\begin{tabular}{|c|c|c|}
\hline \multirow[b]{2}{*}{ No. } & Kriteria & Jumlah \\
\hline & $\begin{array}{l}\text { Total perusahaan manufaktur yang terdaftar di BEI tahun 2013- } \\
2017\end{array}$ & 159 \\
\hline 1 & $\begin{array}{l}\text { Perusahaan manufaktur yang terdaftar dan tidak delisting di BEI } \\
\text { selama periode 2013-2017 }\end{array}$ & (14) \\
\hline 2 & $\begin{array}{l}\text { Perusahaan manufaktur yang menerbitkan laporan keuangan } \\
\text { berturut-turut dari tahun 2013-2017 }\end{array}$ & $(15)$ \\
\hline 3 & $\begin{array}{l}\text { Perusahaan yang menyajikan laporan keuangan dalam mata uang } \\
\text { Rupiah periode } 2013-2017\end{array}$ & $(25)$ \\
\hline 4 & $\begin{array}{l}\text { Perusahaan yang memiliki laba sebelum pajak positif periode } \\
\text { 2013-2017 }\end{array}$ & $(41)$ \\
\hline 5 & $\begin{array}{l}\text { Perusahaan manufaktur yang mencantumkan kompensasi } \\
\text { manajemen dalam laporan keuangan }\end{array}$ & $(14)$ \\
\hline \multicolumn{2}{|c|}{ Data outlier } & $(9)$ \\
\hline \multicolumn{2}{|c|}{ Jumlah perusahaan yang memenuhi kriteriaa penelitian } & 41 \\
\hline \multicolumn{2}{|c|}{ Jumlah observasi 2013-2017 (41 perusahaan x 5 tahun) } & 205 \\
\hline
\end{tabular}

Sumber: Data diolah, 2018

Deskripsi variabel dalam penelitian dilakukan pada variabel kompensasi manajemen, inventory intensity ratio, profitabilitas, dan tax avoidance. Tabel 3 menunjukkan nilai minimum, nilai maksimum, nilai mean dan standar deviasi dari masing-masing variabel.

Tabel 3. Hasil Uji Statistik Deskriptif

\begin{tabular}{llllll}
\hline & \multicolumn{5}{c}{ Descriptive Statistics } \\
\cline { 2 - 6 } & $\mathrm{N}$ & Minimum & Maximum & Mean & Std. Deviation \\
\hline Kompensasi Manajemen & 205 & 17,1095 & 27,5838 & 23,572078 & 1,7200940 \\
Inventory Intensity Ratio & 205 & 0,0110 & 0,6324 & 0,200271 & 0,1207169 \\
Profitabilitas & 205 & 0,0010 & 0,5640 & 0,114463 & 0,1050712 \\
Tax Avoidaance & 205 & 0,0336 & 0,5957 & 0,255647 & 0,0795955 \\
Valid N (listwise) & 205 & & & & \\
\hline
\end{tabular}
Sumber: Data diolah, 2018

Tax avoidance pada penelitian ini diproksikan dengan GAAP ETR yang diukur dengan membandingkan antara beban pajak dan laba sebelum pajak. Hasil uji statistik deskriptif mendapatkan nilai minimum ETR sebesar 0,0336 pada 
ULTJ tahun 2017 dan nilai maksimum sebesar 0,5957 pada AUTO tahun 2015. Variabel tax avoidance memiliki nilai rata-rata sebesar 0,255647. Hal ini menunjukkan bahwa rata-rata perusahaan yang dijadikan sampel memiliki beban pajak sebesar 25,5647 persen dari laba sebelum pajak perusahaan. Standar deviasi tax avoidance sebesar 0,0795955 menunjukkan nilai yang lebih rendah dibandingkan dengan nilai rata-rata, hal ini berarti sebaran data tax avoidance telah merata dan cenderung homogen karena nilai standar deviasi mendekati nol.

Kompensasi manajemen diukur dengan menggunakan proksi logaritma natural dari nilai total kompensasi yang diterima direksi selama satu tahun. Variabel kompensasi manajemen memiliki nilai minimum sebesar 17,1095 pada perusahaan DVLA tahun 2016 dan nilai maksimum sebesar 27,5838 pada perusahaan INDF tahun 2017. Variabel kompensasi manajemen memiliki nilai rata-rata sebesar 23,572078. Standar deviasi kompensasi manajemen yaitu 1,7200940 yang berarti data kompensasi manajemen bervariasi dengan sebaran data normal.

Hasil uji statistik deskriptif menunjukkan nilai minimum inventory intensity ratio sebesar 0,011 pada perusahaan ROTI tahun 2017 dan nilai maksimum sebesar 0,6324 pada perusahaan HMSP tahun 2013. Variabel inventory intensity ratio memiliki nilai rata-rata sebesar 0,200271 yang menunjukkan rata-rata jumlah persediaan yang dimiliki perusahaan sebesar 20,0271 pesen dari total aset perusahaan yang dijadikan sampel. Standar deviasi yaitu 0,1207169 menunjukkan nilai yang lebih rendah dibandingkan dengan nilai 
rata-rata, hal ini berarti sebaran data inventory intensity ratio telah merata dan cenderung homogen karena nilai standar deviasi mendekati nol.

Profitabilitas diukur menggunakan proksi ROA. Nilai minimum sebesar 0,0010 pada perusahaan SCCO tahun 2015. Nilai maksimum ROA sebesar 0,564 pada perusahaan UNVR tahun 2013 dan nilai rata-rata sebesar 0,114463. Standar deviasi senilai 0,1050712 lebih rendah dibandingkan dengan nilai rata-rata, hal ini berarti sebaran data tax avoidance sudah merata dan cenderung homogen karena nilai standar deviasi mendekati nol.

Model regresi dalam penelitian ini menggunakan uji asumsi klasik yang terdiri dari: uji normalitas, uji multikolinearitas, uji heteroskedastisitas, dan uji autokorelasi. Pengujian normalitas terhadap residual menggunakan uji Kolmogorov-Smirnov. Tingkat signifikansi yang digunakan $\alpha=0,05$. Tabel 4 menunjukkan bahwa hasil uji Kolmogorov-Smirnov sebesar 0,054 dengan nilai sigifikansi sebesar 0,200. Hasil ini menunjukkan bahwa keempat variabel yaitu kompensasi manajemen, inventory intensity ratio, profitabilitas, dan tax avoidance berdistribusi normal sehingga asumsi normalitas telah terpenuhi

Tabel 4.

Uji Normalitas One-Sample Kolmogorov-Smirnov

\begin{tabular}{lll} 
& \multicolumn{2}{c}{ Test } \\
\hline $\mathrm{N}$ & $\begin{array}{l}\text { Unstandardized } \\
\text { Residual }\end{array}$ \\
Normal & Mean & 205 \\
Parameters & 0,000 \\
& Std. & 1,503 \\
Most Extreme & Deviation & 0,054 \\
Differences & Absolute & 0,028 \\
& Positive & $-0,054$ \\
Test Statistic & Negative & 0,054 \\
Asymp. Sig. (2-tailed) & & $0,200^{\mathrm{c}, \mathrm{d}}$ \\
\hline Sumber: Data diolah, 2018 &
\end{tabular}


Pengujian multikolinearitas menunjukkan bahwa nilai tolerance tiap variabel lebih besar dari 0,10 dan nilai VIF lebih kecil dari 10, hal tersebut menujukkan bahwa tidak terjadi multikolinearitas antara variabel bebas dan asumsi multikolinearitas terpenuhi. Hasil uji multikolinearitas dapat dilihat pada Tabel 5.

Tabel 5.

Uji Multikolinearitas

\begin{tabular}{llll}
\hline & & \multicolumn{2}{l}{$\begin{array}{l}\text { Collinearity } \\
\text { Statistics }\end{array}$} \\
\cline { 3 - 4 } Model & & Tolerance & VIF \\
\hline 1 & X1 & 0,936 & 1,068 \\
& X2 & 0,972 & 1,029 \\
& X3 & 0,917 & 1,091 \\
\hline
\end{tabular}

Sumber: Data diolah, 2018

Penelitian ini menggunakan uji glejser dalam mendeteksi data heteroskedastisitas.. Model regresi menunjukkan terbebas dari heteroskedastisitas dengan nilai signifikan di atas 0,05. Hasil uji heteroskedastisitas disajikan pada Tabel 6.

Tabel 6.

Hasil Uji Heteroskedastisitas

\begin{tabular}{lllllll}
\hline Model & & \multicolumn{2}{l}{ Unstandardized Coefficients } \\
B & & $\begin{array}{l}\text { Standardized } \\
\text { Coefficients } \\
\text { Beta }\end{array}$ & T & Sig. \\
\hline 1 & (Constant) & 2,460 &, 897 & & 2,744 &, 007 \\
& X1 &,- 057 &, 039 &,- 107 & $-1,481$ &, 140 \\
& X2 &, 259 &, 539 &, 034 &, 481 &, 631 \\
& X3 &, 060 &, 637 &, 007 &, 095 &, 925
\end{tabular}

a. Dependent Variable: Absolut Residual Sumber: Data diolah, 2018

Autokorelasi dideteksi dengan cara melihat nilai Durbin Watson (DW) yaitu dengan membandingkan nilai DW hitung dengan $d_{L}$ dan $d_{U}$ untuk jumlah sampel $(\mathrm{N})$ sebanyak 41 dengan variabel bebas $(\mathrm{k})$ sebanyak 3 adalah sebesar $\mathrm{d}_{\mathrm{L}}$ 
1,24 dan $\mathrm{d}_{\mathrm{U}} 1,79$. Tabel 7 menunjukkan hasil uji autokorelasi menggunakan uji Durbin-Watson (DW test) sebesar 1,838 lebih besar dari batas atas (du) 1,79 dan kurang dari batas bawah (dL) $4-1,79=2,21(4-\mathrm{du})$, maka disimpulkan bahwa nilai DW $1,79<1,838 \leq 2,21$ yang diperoleh dalam model regresi ini tidak mengandung autokorelasi positif atau negatif. Hasil uji autokorelasi disajikan pada Tabel 7.

Tabel 7.

Hasil Uji Autokorelasi

\begin{tabular}{llllll}
\hline \multicolumn{6}{c}{ Model Summary } \\
\hline Model & $\mathrm{R}$ & R Square & $\begin{array}{l}\text { Adjusted R } \\
\text { Square }\end{array}$ & $\begin{array}{l}\text { Std. Error of the } \\
\text { Estimate }\end{array}$ & Durbin-Watson \\
\hline 1 &, $243^{\mathrm{a}}$ &, 059 &, 045 &, 0777764 & 1,838 \\
\hline
\end{tabular}

a. Predictors: (Constant), X3, X2, X1

b. Dependent Variable: Y

Sumber: Data diolah, 2018

Tabel 8 menunjukkan bahwa besarnya nilai Adjusted $R$ Square sebesar 0,045 memiliki arti bahwa sebesar 4,5 persen variasi tax avoidance dapat dijelaskan oleh variabel kompensasi manajemen $\left(\mathrm{X}_{1}\right)$, inventory intensity ratio $\left(\mathrm{X}_{2}\right)$, dan profitabilitas. Sisanya sebesar 95,5 persen dipengaruhi oleh variabel lain yang tidak dimasukkan dalam penelitian ini.

Tabel 8.

Hasil Uji Determinasi

\begin{tabular}{lllll} 
Model & $\mathrm{R}$ & R Square & $\begin{array}{l}\text { Adjusted R } \\
\text { Square }\end{array}$ & $\begin{array}{l}\text { Std. Error } \\
\text { of the } \\
\text { Estimate }\end{array}$ \\
\hline 1 &, $243^{\mathrm{a}}$ &, 059 &, 045 &, 0777764 \\
\hline Sumber: Data diolah, 2018 & & &
\end{tabular}

Tabel 9 menunjukkan bahwa nilai $\mathrm{F}$ hitung sebesar 4,218 dengan tingkat signifikansi sebesar 0,006. Nilai tersebut lebih kecil dari $\alpha=0,05$. Hasil tersebut menunjukkan bahwa variabel-variabel independen beserta interaksinya 
berpengaruh terhadap variabel dependennya yaitu tax avoidance. Hasil tersebut menunjukkan bahwa model persamaan dalam penelitian ini layak untuk digunakan.

Tabel 9.

Hasil Uji Simultan (F-TEST)

\begin{tabular}{lllllll}
\hline Model & & $\begin{array}{l}\text { Sum of } \\
\text { Squares }\end{array}$ & df & $\begin{array}{l}\text { Mean } \\
\text { Square }\end{array}$ & F & Sig. \\
\hline 1 & Regression &, 077 & 3 &, 026 & 4,218 &, $006^{\mathrm{b}}$ \\
& Residual & 1,216 & 201 &, 006 & & \\
& Total & 1,292 & 204 & & & \\
\hline
\end{tabular}

Sumber: Data diolah, 2018

Tabel 10 menunjukkan persamaan regresi yang digunakan dalam penelitian ini yaitu:

$$
\mathrm{Y}=0,097+0,007 \mathrm{X}_{1}+0,069 \mathrm{X}_{2}-0,164 \mathrm{X}_{3}+{ }^{\varepsilon} \mathcal{E}
$$

Nilai konstanta sebesar 0,097 dengan $P_{\text {value }}$ sebesar $0,204>0,005$ menunjukkan jika kompensasi manajemen $\left(\mathrm{X}_{1}\right)$, inventory intensity ratio $\left(\mathrm{X}_{2}\right)$, dan profitabilitas $\left(\mathrm{X}_{3}\right)$ bernilai nol, maka besarnya tingkat tax avoidance $(\mathrm{Y})$ yang diproksikan dengan ETR tidak bisa dimaknai. Nilai koefisien $\beta_{1}$ sebesar 0,007 menunjukkan jika kompensasi manajemen $\left(\mathrm{X}_{1}\right)$ meningkat sebesar 1 satuan, maka ETR sebagai proksi tax avoidance meningkat sebesar 0,007 satuan dengan asumsi variabel independen lainnya konstan. Semakin rendah nilai ETR mencerminkan semakin tingginya tingkat tax avoidance dan sebaliknya, sehingga peningkatan nilai ETR perusahaan menunjukkan rendahnya tingkat tax avoidance (Y).

Nilai koefisien $\beta_{2}$ sebesar 0,069 menunjukkan jika inventory intensity ratio $\left(\mathrm{X}_{2}\right)$ meningkat sebesar 1 satuan, maka ETR sebagai proksi tax avoidance meningkat sebesar 0,069 satuan dengan asumsi variabel independen lainnya 
konstan. Semakin rendah nilai ETR mencerminkan semakin tingginya tingkat tax avoidance dan sebaliknya, sehingga peningkatan nilai ETR perusahaan menunjukkan rendahnya tingkat tax avoidance (Y). Nilai koefisien $\beta_{3}$ sebesar $-0,164$ menunjukkan jika nilai profitabilitas $\left(\mathrm{X}_{3}\right)$ m sebesar 1 satuan, maka ETR sebagai proksi tax avoidance menurun sebesar 0,164 satuan dengan asumsi variabel independen lainnya konstan. Semakin rendah nilai ETR mencerminkan semakin tingginya tingkat tax avoidance dan sebaliknya, sehingga penurunan nilai ETR perusahaan menunjukkan peningkatan tindakan tax avoidance (Y) yang dilakukan perusahaan.

Tabel 10.

Hasil Uji t-test

\begin{tabular}{llllll}
\hline Model & \multicolumn{2}{l}{ Unstandardized Std. Error } & $\begin{array}{l}\text { Standardized } \\
\text { Coefficients } \\
\text { Beta }\end{array}$ & $\mathrm{t}$ & Sig. \\
\hline (Constant) & 0,097 & 0,076 & & 1,274 & 0,204 \\
$\begin{array}{l}\text { Kompensasi } \\
\text { Manajemen }\end{array}$ & 0,007 & 0,003 & 0,150 & 2,122 & 0,035 \\
$\begin{array}{l}\text { Inventory } \\
\text { Intensity Ratio }\end{array}$ & 0,069 & 0,046 & 0,104 & 1,505 & 0,134 \\
Profitabilitas & $-0,164$ & 0,054 & $-0,217$ & $-3,036$ & 0,003 \\
\hline
\end{tabular}

Sumber: Data diolah, 2018

Hipotesis pertama menyatakan kompensasi manajemen memiliki pengaruh negatif terhadap tax avoidance. Nilai koefisien kompensasi manajemen sebesar 0,007 dengan nilai $P$-value sebesar 0,035 lebih kecil dari $\alpha=0,05$. Hasil ini mencerminkan bahwa kompensasi manajemen berpengaruh positif pada ETR sebagai proksi dari tax avoidance. Nilai koefisien regresi $\beta_{1}$ sebesar 0,007 menunjukkan hubungan positif antara kompensasi manajemen dengan ETR. Semakin tinggi kompensasi manajemen yang diberikan maka nilai ETR 
perusahaan meningkat. Hal ini berarti kompensasi manajemen berpengaruh negatif pada tax avoidance. Semakin tinggi kompensasi yang diberikan maka semakin rendah tingkat tax avoidance perusahaan, sehingga hipotesis pertama diterima.

Hasil penelitian ini mengonfirmasi Theory of Planned Behaviour yang menjelaskan bahwa perilaku individu terhadap perilaku tertentu timbul karena adanya niat seorang individu. Pemberian kompensasi sebagai kontrol terhadap kinerja manajemen yang pengukurannya sebagian besar berdasarkan laba sehingga mendorong manajemen untuk bersikap oportunis dalam melakukan tax avoidance (Croci et al., 2012), sedangkan pemilik menginginkan perusahaan dengan masa depan yang terjamin keberlanjutannya dan investasi yang aman oleh karena itu kompensasi diberikan terhadap manajemen untuk meminimalisir tindakan oportunistik manajemen dalam melakukan tax avoidance.

Hasil penelitian ini mendukung penelitian dari Zulma (2015) dan (Armstrong et al., 2012) yang mendapatkan adanya pengaruh negatif antara kompensasi manajemen dengan tax avoidance. Penghindaran pajak menimbulkan risiko untuk masa depan perusahaan oleh karena itu pemilik mengeluarkan kompensasi kepada manajemen untuk meminimalir sikap oportunis dalam melakukan tax avoidance.

Hipotesis kedua menyatakan inventory intensity ratio memiliki pengaruh positif pada tax avoidance. Tabel 4.7 menunjukkan bahwa nilai koefisien inventory intensity ratio sebesar 0,069 dengan nilai P-value sebesar 0,134 lebih besar dari $\alpha=0,05$. Hasil ini menunjukkan bahwa inventory intensity ratio tidak 
berpengaruh pada ETR. Hasil pengujian ini tidak dapat mendukung hipotesis kedua yang menyatakan inventory intensity ratio berpengaruh positif pada tax avoidance.

Hasil ini tidak dapat mendukung theory of planned behavior yang menjelaskan bahwa biaya tambahan atas persediaan akan mendorong intensi dalam penurunan laba yang akan membentuk sikap (attitude) dengan melakukan tax avoidance. Intensi timbul dari keyakinan manajemen mengenai harapan normatif orang lain seperti pihak prinsipal yang memiliki harapan untuk mendapatkan keuntungan tinggi dengan pembayaran beban yang seminimal mungkin, sehingga pihak manajemen menjadi termotivasi untuk memenuhi harapan tersebut (normative beliefs).

Biaya tambahan yang timbul atas persediaan tidak dapat mempengaruhi tindakan tax avoidance perusahaan. Hal ini tercermin dari rata-rata inventory intensity perusahaan sampel pada penelitian ini cukup rendah, yaitu sebesar 20,03 persen. Dari 41 sampel perusahaan, hanya 2 perusahaan yang memiliki nilai rata-rata inventory intensity ratio diatas 50 persen yaitu GGRM dan HMSP. Sehingga dapat dikatakan bahwa biaya tambahan yang timbul akibat investasi perusahaan pada persediaan tidak terlalu berpengaruh terhadap pengurangan penghasilan kena pajak. Data sampel perusahaan menunjukkan perusahaan lebih banyak menginvestasikan pada aset tetap dibandingkan dengan persediaan. Hasil penelitian ini sejalan dengan penelitian yang dilakukan oleh Anindyka dkk., (2018) yang mendapatkan tidak adanya pengaruh antara inventory intensity ratio pada tax avoidance.

Hipotesis ketiga menyatakan profitabilitas memiliki pengaruh negatif pada tax avoidance. Tabel 10 menunjukkan bahwa nilai koefisien profitabilitas sebesar 
-0,164 dengan nilai P-value sebesar 0,03 lebih kecil dari $\alpha=0,05$. Hasil ini menunjukkan bahwa profitabilitas memiliki pengaruh terhadap ETR sebagai proksi dari tax avoidance. Nilai koefisien regresi $\beta_{1}$ yaitu $-0,164$ menunjukkan hubungan negatif antara profitabilitas dengan ETR. Semakin tinggi profitabilitas maka nilai ETR semakin rendah. Artinya, semakin tinggi profitabilitas perusahaan maka tax avoidance perusahaan meningkat, sehingga hipotesis ketiga ditolak.

Hasil penelitian ini tidak dapat mendukung Theory of Planned of Behaviour yang menyatakan apabila perusahaan memiliki profitabilitas yang tinggi, maka perusahaan akan merencanakan perilaku yang taat dan patuh membayar beban pajaknya karena perusahaan dengan profit yang tinggi dianggap mampu membayar pajaknya sehingga menurunnya tindakan tax avoidance. Profitabilitas memiliki pengaruh positif pada tax avoidance dikarenakan berdasarkan data dari perusahaan sampel peningkatan ROA tidak diikuti dengan peningkatan ETR. Perusahaan yang mengalami peningkatan profitabilitas tidak menjamin efisiensi pengelolaan perusahaan, hal ini dilihat dari peningkatan aset perusahaan sampel tidak diikuti dengan peningkatan beban pajak perusahaan. Hasil penelitian ini mendukung penelitian dari (Darmawan \& Sukartha, 2014) yang mendapatkan hasil ROA memiliki pengaruh positif pada tax avoidance.

Penelitian ini menghasilkan bukti empiris bahwa kompensasi manajemen memiliki pengaruh negatif pada tax avoidance. Penelitian ini mendukung theory of planned behaviour yaitu normative beliefs dan control beliefs yang menjelaskan keyakinan individu mengenai harapan normatif orang sehingga termotivasi untuk memenuhinya. Perusahaan yang tidak melakukan tax avoidance mencerminkan kinerja perusahaan yang baik dapat meningkatkan reputasi 
perusahaan, sehingga meningkatkan kepercayaan masyarakat dan membantu perusahaan dalam mendapatkan laba. Hasil penelitian ini bermanfaat sebagai masukan bagi perusahaan yang diteliti yaitu perusahaan manufaktur sehingga risiko yang ditanggung dari setiap keputusan lebih diperhatikan.

\section{SIMPULAN}

Simpulan yang dapat ditarik berdasarkan hasil analisis pembahasan pada hasil penelitian yaitu: (1) Kompensasi manajemen berpengaruh negatif pada tax avoidance, yang artinya pemberian kompensasi manajemen mampu mengurangi tindakan tax avoidance perusahaan. Pemberian kompensasi manajemen untuk mengurangi oportunistik manajemen dalam melakukan penghindaran pajak untuk menjamin keberlanjutan masa depan perusahaan dan investasi terjaga aman sehingga pemilik perusahaan memberikan sejumlah kompensasi kepada manajemen. (2) Hasil pengujian ini tidak dapat mendukung hipotesis yang menyatakan inventory intensity ratio berpengaruh positif pada tax avoidance. (3) Hasil pengujian ini tidak dapat mendukung hipotesis yang menyatakan profitabilitas berpengaruh negatif pada tax avoidance.

Saran yang dapat diberikan peneliti untuk penelitian selanjutnya yaitu: (1) Nilai adjusted $R$ square yang rendah yaitu sebesar 4,5 persen menunjukkan bahwa terdapat keterbatasan variabel independen dalam menjelaskan variabel dependen (tax avoidance). Bagi peneliti selanjutnya diharapkan dapat meneliti variabel lain yang dapat mendeteksi adanya tindakan tax avoidance seperti leverage, capital intensity ratio, ukuran perusahaan, dan CSR. (2) Ruang lingkup penelitian ini hanya menggunakan perusahaan manufaktur yang terdaftar di Bursa Efek 
Indonesia, oleh karena itu penelitian ini tidak dapat digeneralisasi untuk seluruh perusahaan yang terdaftar di Bursa Efek Indonesia. Penelitian ini hanya menggunakan periode empat tahun. Penelitian selanjutnya diharapkan dapat mengatasi keterbatasan dalam penelitian ini, melalui penggunaan periode pengamatan yang berbeda dan menambah periode pengamatan sehingga dapat digunakan untuk memprediksi dan mendapatkan hasil penelitian yang semakin baik.

\section{REFERENSI}

Ajzen, I. (1991). The Theory of Planned Behavior. Organizational Baheviour and Human Decision Process, 50, pp. 179-211.

Anindyka, D., Pratomo, D., \& Kurnia. (2018). Pengaruh Leverage ( DAR ), Capital Intensity dan Inventory Intensity terhadap Tax Avoidance (Studi Pada Perusahaan Makanan dan Minuan di Bursa Efek Indonesia ( BEI ) Tahun 2011- 2015 ). E-Proceeding of Management, 5(1), hal. 713-719.

Armstrong, C. S., Blouin, J. L., \& Larcker. (2015). Corporate Governance , Incentives, and Tax Avoidance. Journal of Accounting and Economics1, 60(1), hal. 1-17.

Armstrong, C. S., Ittner, C. D., \& Larcker, D. F. (2012). and CEO pay levels, pp 322-351.

Chalmers, K., Koh, P.-S., \& Stapledon, G. (2006). The Determinant of CEO Compensation: Rent Extraction or Labor Demand. The British Accounting Review, pp. 1-17.

Chen, S., Chen, X., Shevlin, T., \& Cheng, Q. (2010). Are Family Firms More Tax Aggressive Than Non-Family Firms? Journal of Financial Economics, pp. $41-61$.

Croci, E., Gonenc, H., \& Ozkan, N. (2012). CEO Compensation, Family Control and Institutional Investor in Continental Europe. Journal of Banking and Finance, 36, pp. 3318-3335.

Darmadi, I. N. H., \& Zulaikha. (2013). Analisis faktor yang mempengaruhi manajemen pajak dengan indikator tarif pajak efektif. Diponogoro Journal of Accounting, 2(4), hal. 1-12. 
Darmawan, I. G. H., \& Sukartha, I. M. (2014). Pengaruh Penerapan Corporate Governance, Leverage, Return On Assets, dan Ukuran Perusahaan pada Penghindaran Pajak. E-Jurnal Akuntansi Universitas Udayana, 9(1), hal. 143-161.

Dewinta, I. A. R., \& Setiawan, P. E. (2016). Pengaruh Ukuran Perusahaan, Umur Perusahaan, Profitabilitas, Leverage, dan Pertumbuhan Penjualan terhadap Tax Avoidance. E- Jurnal Akuntansi Universitas Udayana, 14(3), hal. 15841613.

Faizah, S. N., \& Adhivinna, V. V. (2017). Pengaruh Return On Asset, Leverge, Kepemilikan Institusional dan Ukuran Pperusahaan terhadap Tax Avoidance. Jurnal Akuntansi, 5(2), hal. 136-145.

Fajar, M., Zulbahridar, \& Kurnia, P. (2018). Pengaruh Profitabilitas, Leverage, dan Corporate Governance terhadap Tax Avoidance (Studi Empiris pada Perusahaan Manufaktur yang Terdaftar di Bursa Efek Indonesia Periode 2012-2014). Jurnal Online Mahasiswa FEB, 1(1), 300.

Gaertner, F. B., Campbell, J., Cook, K., Dikolli, S., Dyreng, S., Hoopes, J., ... Martin, M. (2010). CEO After-tax Compensation Incentives and Corporate Tax Avoidance.

Gandy Wahyu Maulana Zulma, D. M. (2015). Pengaruh Kompensasi Manajemen berbasis Saham terhadap Manajemen Pajak Perusahaan dengan Mempertimbangkan Fungsi Pengawasan Komite Audit. Jurnal Riset Akuntansi Dan Keuangan Universitas Pendidikan Indonesia. https://doi.org/http://dx.doi.org/10.17509/jrak.v3i2.6611

Hanlon, M., \& Heitzman, S. (2010). A Review of Tax Research. Journal of Accounting and Economics, 50(2-3), 127-178. https://doi.org/10.1016/j.jacceco.2010.09.002

Irawan, H. P., \& Farahmita, A. (2012). Pengaruh Manajemen dan Corporate Governance terhadap Manajemen Pajak. Jurnal Akuntansi Dan Keuangan Indonesia.

Lestari, D. (2015). Pengaruh Corporate Governance Dan Intensitas Persediaan Terhadap Manajemen Pajak (Studi Empiris Pada Perusahaan Manufaktur Yang Terdaftar Di Bursa Efek Indonesia Tahun 2011-2013). Jom FEKON, 2(2).

Mccolgan . (2001). Agency Theory and Corporate Governance: A Review of the Literature from a UK Perspective, (May), pp. 1-44. 
Minnick, K., \& Noga, T. (2010). Do corporate governance characteristics influence tax management? Journal of Corporate Finance.

Murphy, K. (2004). Aggressive Tax Planning: Differentiating Those Playing The Game from Those Who Don't. Journal of Economic Psychology, 25, pp. 307-329.

Noor, R., Fadzillah, N. S. M., \& Mastuki. (2010). Corporate Tax Planning: A Study On Corporate Effective Tax Rates of Malaysian Listed Companies, 1(2), pp. 189-193.

Nugrahitha, I. M. A., \& Suprasto, H. B. (2018). Pengaruh Profitabilitas, Leverage , Corporate Governance, dan Karakter Eksekutif pada Tax Avoidance. EJurnal Akuntansi Universitas Udayana, 22(36), hal. 2016-2039.

Putri, M. C. A. (2017). Pengaruh Kompensasi Manajemen, Corporate Governance, Reputasi Auditor terhadap Manajemen Pajak. JOM Fekon, 4(1), hal. 294-308.

Richardson, G., \& Lanis, R. (2007). Determinants of the variability in corporate effective tax rates and tax reform: Evidence from Australia. Journal of Accounting and Public Policy, 26, hal. 689-691.

Siregar, R., \& Widyawati, D. (2016). Pengaruh Karakteristik Perusahaan Terhadap Penghindaran Pajak pada Perusahaan Manufaktur yang Terdaftar di Bursa Efek Indonesia. Jurnal Ilmu Riset Dan Akuntansi, 5(2).

Slemrord, J. (1989). Complexity, Compliance Cost, and Tax Evasion. An Agenda for Compliance Research. Philadelphia, 2.

Sugiyono. (2009). Metode Penelitian Kuantitatif, Kualitatif dan R\&D. Bandung: Alfabeta.

Surbakti, T. A. (2012). Pengaruh Karakteristik Perusahaan dan Reformasi Perpajakan Terhadap Penghindaran Pajak di Perusahaan Manufaktur. Skripsi.

Xynas, L. (2011). Tax Planning, Avoidance and Evasion in Australia 1970-2010: The Regulatory Responses and Taxpayer Compliance. Revenue Law Journal, 20(1), 2.

Zulma, G. W. M. (2016). Pengaruh Kompensasi Manajemen terhadap Penghindaran Pajak Perusahaan dengan Moderasi Kepemilikan Keluarga di Indonesia. Simposium Nasional Akuntansi XIX, hal. 1-15. 